\title{
Trade Liberalisation, Financial Development and Economic Growth
}

\author{
Muhammad Arshad Khan
}

Abdul Qayyum 
PIDE Working Papers

2007:19

\title{
Trade Liberalisation, Financial Development and Economic Growth
}

\author{
Muhammad Arshad Khan \\ Research Associate \\ Pakistan Institute of Development Economics, Islamabad \\ and \\ Abdul Qayyum \\ Associate Professor \\ Pakistan Institute of Development Economics, Islamabad
}

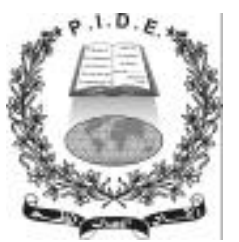

PAKISTAN INSTITUTE OF DEVELOPMENT ECONOMICS ISLAMABAD 
All rights reserved. No part of this publication may be reproduced, stored in a retrieval system or transmitted in any form or by any means-electronic, mechanical, photocopying, recording or otherwise-without prior permission of the author(s) and or the Pakistan Institute of Development Economics, P. O. Box 1091, Islamabad 44000.

\section{(C) Pakistan Institute of Development}

\section{Economics, 2007.}

Pakistan Institute of Development Economics

Islamabad, Pakistan

E-mail: publications@ pide.org.pk

Website: http://www.pide.org.pk

Fax: $\quad+92-51-9210886$

Designed, composed, and finished at the Publications Division, PIDE 


\section{O N T E N T S}

Page

Abstract v v v

1. Introduction 1

2. Review of Existing Literature 3

2.1. Finance and Economic Growth 3

2.2. Trade and Economic Growth 8

3. Overview of the Financial and Trade Policies in Pakistan 10

3.1. Financial Sector Reforms 10

3.2. Trade Liberalisation 16

4. Model Specification, Methodology and Data Issues 18

4.1. Data Description 21

4.2. Construction of Financial Development Index (FSDI) 22

5. Empirical Results 23

6. Conclusions 27

References $\quad 27$

\section{List of Tables}

Table 1. Interest Rate Behaviour in Pakistan 13

Table 2. Indicators of Financial Deepening (in percent) 15

Table 3. Growth Rates of Exports and Imports and Degree of Openness (in percent) 18

Table 4. Financial Sector Development Index (FSDI) 22

Table 5. Statistics for Selecting Lag Order and the Existence of Long-run Relationship 23

Table 6. ARDL Estimates 24

Table 7. Error Correction Representation of ARDL Model 25 


\section{List of Figures}

Figure 1. Financial Development Indicator Relative to GDP 16

Figure 2. Exports, Imports, and Degree of Openness (in percent) 18

Figure 3. Financial Sector Development Index (FSDI) 22

Figure 4. Plot of Cumulative Sum of Recursive Residuals 26

Figure 5. Plot of Cumulative Sum of Squares of Recursive Residuals 26 


\begin{abstract}
This paper empirically investigates the impact of trade and financial liberalisation on economic growth in Pakistan using annual observations over the period 1961-2005. The analysis is based on the bound testing approach of cointegration advanced by Pesaran, et al. (2001). The empirical findings suggest that both trade and financial policies play an important role in enhancing economic growth in Pakistan in the long-run. However, the short-run responses of the real deposit rate and trade policy variables are very low, suggesting further acceleration of the reform process. The feedback coefficient suggests a very slow rate of adjustment towards long-run equilibrium. The estimated equation remains stable over the period of study as indicated by CUSUM and CUSUMQ stability tests.
\end{abstract}

JEL classification: $\mathrm{F} 43, \mathrm{G} 10, \mathrm{O} 10, \mathrm{C} 22$

Keywords: Trade Liberalisation, Financial Development, Economic Growth, Bound Test 



\section{INTRODUCTION}

The relationship between trade liberalisation, finance reforms and economic growth has been well documented in the economic literature. A considerable body of literature suggests a strong and positive link between trade liberalisation, financial development and economic growth. It has been argued that trade and financial liberalisation policies reduce the inefficiency in the production process and positively influence economic growth. This argument is strengthened by the fact that countries with more open trade and financial policies may grow faster than those with restricted trade and financial policies. An increasing openness is expected to have positive impacts on economic growth [Jin (2000); Fry (1995, 1997); Darrat (1999); Levine (1997); Mckinnon (1973); Shaw (1973) and World Bank (1989)]. There is growing consensus that both liberalisation policies are expected to exert positive impacts on economic growth.

Shumpeter (1911) argued that services provided by financial intermediaries are essential for economic development. Financial liberalisation deepens financial markets and thereby promotes economic growth [Mckinnon (1973) and Shaw (1973)]. Steps towards financial and trade liberalisation were taken by many developing countries including Pakistan to achieve higher level of growth. Thus, an empirical research is needed to determine the effectiveness of financial and trade liberalisation policies with regard to growth in a developing country like Pakistan. Examining the impacts of both policies is particularly important in the case of Pakistan, which followed restrictive policies till early 1990s. The costs of these restrictive policies have been enormous and reflected in a low level of financial savings, investment and economic growth.

The positive relationship between financial and trade variables and economic growth is explained by incorporating efficiency effects which mainly results from the reduction of rent seeking and from the gains in internal and external economies of scale due to financial and trade liberalisation [Bhagwati (1988); Lee (1993); Krueger (1998); Fry (1995, 1997)]. This efficiency effect considered as a major source of long-run growth. The endogenous growth theory

Acknowledgements: We are grateful to Dr Nadeem Ul Haque, Vice-Chancellor, PIDE for providing an opportunity to complete this study. We are also thankful to Dr Ejaz Ghani, Senior Research Economist, PIDE for his invaluable comments which helped to improve this study. Thanks are also due to Mr Khalid Mirza, Chairman, Monopoly Control Authority, Islamabad and other participants of the 22nd AGM of PSDE for their valuable comments and suggestions.

Muhammad Arshad Khan is Associate Professor at Government Postgraduate College Muzaffarabad (Azad Kashmir) and currently he is working as Research Associate at the Pakistan Institute of Development Economics, Islamabad. Abdul Qayyum is Associate Professor at the Pakistan Institute of Development Economics, Islamabad. 
predicts that both financial and trade liberalisation along with investment in physical and human capital enhance economic growth [Romer (1986); Lucas (1988); Rivera -Batiz and Romer (1991) and King and Levine (1993)].

Research suggests that financial deepening effectively channels savings to productive investment opportunities, improves corporate governance, reduces transaction and information costs, and enhances specialisation, and so forth [Bencivenga and Smith (1991); De Gregorio and Guidotti (1995); Greenwood and Jovanovic (1990); Levine (2004)].

Financial development can affect growth through three main channels [Aziz and Duenwald (2002)]: (i) it can increase the marginal productivity of capital by collecting information to evaluate alternative investment projects and by risk sharing; (ii) it can raise the proportion of savings channeled to investment via financial development-by reducing the resources absorbed by financial intermediaries and thus increasing the efficiency of financial intermediation; and (iii) it can raise the private saving rate. Moreover, Ansari (2002) has noted that financial development contribute to economic growth in the following ways: (i) financial markets enable small savers to pool funds, (ii) savers have a wider range of instruments stimulating savings, (iii) efficient allocation of capital is achieved as the proportion of financial saving in total wealth rises, (iv) more wealth is created as financial intermediaries redirect savings from the individuals and the slow-growing sectors to the fast-growing sectors, (v) financial intermediaries partially overcome the problem of adverse selection in the credit market, and (vi) financial markets encourages specialisation in production, development of entrepreneurship, and adoption of new technology.

Similarly, removal of trade restrictions helps to stabilise the development process by improving efficiency and return economies from distorted factor prices to production frontiers. Moreover, trade openness will improve domestic technology, production process will be more efficient, and hence productivity will rise [Jin (2000)]. Trade liberalisation and growth relations may occur through investment, and trade openness may provide greater access to investment goods [Levine and Renelt (1992)]. Countries that liberalise their external sector and reduce impediments to international trade can experience relatively higher economic growth. It is generally agreed that an open trade regime is crucial for economic growth and development [Sukar and Ramakrishna (2002)].

The main objective of both liberalisation policies is to increase productivity through reducing inefficiency in investment. The existing literature examines the impact of financial ${ }^{1}$ and trade liberalisation ${ }^{2}$ separately despite their shared importance in increasing efficiency of investment. The empirical

${ }^{1}$ Khan, et al. (2005).

${ }^{2}$ Din, et al. (2003). 
evidence related to the joint impact of financial and trade variable on economic growth is underdeveloped. The joint impact of trade and finance was initially highlighted by Roubini and Sala-i-Martin (1991) and Barro (1991). The inclusion of both variable by Roubini and Sala-i-Martin (1991) highlighted the importance of both financial and trade variables in the economic growth. Thus our testable hypothesis is that both financial development and trade liberalisation jointly increase economic growth.

This paper makes three main contributions to the empirical literature on trade, finance and growth. First, it examines the joint impact of trade liberalisation and financial development on growth in Pakistan. Second, unlike previous studies instead of using different indicators of financial development separately, we used financial development index as a proxy for government financial policy to assess its impact on real GDP. Thirdly, it applies recent econometric techniques of cointegration namely, the bound testing approach to cointegration developed by Pesaran, et al. (2001) to examine the relationship between trade, finance and growth. This modeling technique does not require any precise identification of the order of integration of the underlying data. Furthermore, ARDL estimation is applicable even the explanatory variables are endogenous, and the existence of a long run relationship is independent of whether the explanatory variables are I (0), or I (1).

The rest of the paper is organised as follows: Section 2 deals with the brief overview of the financial and trade policies being pursued by Pakistan. Section 3 explains the model specification, data issues and econometric methodology. Empirical findings are discussed in Section 4, while some concluding remarks are given in the final section.

\section{REVIEW OF EXISTING LITERATURE}

A large body of theoretical and empirical literature provides ample evidence of significant contributions of finance and economic growth and trade liberalisation to the economic development. This section is devoted to review some theoretical and empirical literature.

\subsection{Finance and Economic Growth}

The importance of financial development for economic growth can be traced back as Bagehot (1873), Schumpeter (1911) and Hicks (1969). More recent work includes Levine (1998), King and Levine (1993, 1993a), Rousseau and Wachtel (1998), Rajan and Zingales (1998), and Okedokun (1998). Bagehot (1873) and Hicks (1969) argued that the financial system was an important catalyst in the industrialisation of England by facilitating the movement of large amount of funds for "immense" work. Bagehot (1873) noted:

.... We have entirely lost the idea that any undertaking likely to pay, and seen to likely, can perish for want of money; yet no idea was more 
familiar to our ancestors, or is more common in most countries. A citizen of London in Queen Elizabeth's time ... would have thought that it was no use inventing railways (if he could have understood what a railway meant), for you would have not been able to collect that capital with which to make them. At this movement, in colonies and all rude economies, there is no large sum of transferable money; there is no fund from which you can borrow, and out of which you can make immense work... (pp. 3-4)

Schumpter's view is that a well-functioning financial system would induce technological innovation by identifying, selecting and funding those entrepreneurs that would be expected to successfully implement their products and productive processes.

By studying 80 countries over the period 1960-89, recently, King and Levine (1993a) found a highly significant relationship between the initial value of the ratio of liquid liabilities to GDP in 1960 and real per capita income. Furthermore, the lack of financial development could be possibly inducing some form of "poverty trap" because of the possible existence of multiple steady state equilibria [Sinha and Macri (2001)]. However, the other economists have questioned the casual relationshis established in the empirical studies. For example, Robinson (1952) claim that "where enterprise leads, finance follows"-it is economic development which creates the demand for financial services not vice versa. Moreover, Lucas (1988) has argued that economists "badly over stress" the importance of the financial system in economic growth-it is simply a "sideshow" for economic activity. In addition, Ram (1999) using data on 95 countries, found that the "empirical evidence does not support the view that financial development promotes economic growth". However, many theoretical and empirical studies suggest a positive first order relationship [Levine (1997)].

Levine (1997) argued that a financial system perform five basic tasks: (1) facilitate the trading, hedging, diversifying, and pooling of risk, (2) allocate resources, (3) monitor managers and exert corporate control, (4) mobilise savings, and (5) facilitate the exchange of goods and services. There is however, a considerable debate on the exact channels through which financial development induces economic growth [Gupta (1984); Spears (1992)]. The theories can be subdivided into two broad schools of thoughts: (1) the structuralists, and (2) the repressionists. The structuralists contend that the quantity and composition of financial variables induces economic growth by directly increasing saving in the form of financial assets, thereby, encouraging capital formation and hence, economic growth [Goldsmith (1969); Gurley and Shaw (1955); Patrick (1966); Thornton (1996); Demetriades and Luintel (1996); Berthelemy and Varoudakis (1998)]. Thus factors such as, financial deepening and the composition of the aggregate financial variables are important for 
economic growth. Kwan and Zhang (1998) show, by employing exogeneity tests for several high performing Asian countries, that financial deepening has had a positive impact on output growth [Sinha and Macri (2001)].

Recently financial deepening literature has been extended by incorporated the stock market as a measure of financial development. Levine and Zervos (1998) utilised that data for 47 countries over the period 1976-93 and found that stock market liquidity and banking development had a positive effect on economic growth, capital accumulation and productivity, even after controlling for various other important factors such as, fiscal policy, trade openness, education and political stability. Singh and Weisse (1998) examined stock market development and capital flows for LDCs. Levine (1998) and Jayaratne and Strahan (1996) examined the relationship between the legal system, banking development and its impact on long-run rates of growth, capital stock and productivity and found that when intrastate banking restrictions were relaxed, real per capita GDP rose quite significantly.

The financial repressionists, led by McKinnon (1973) and Shaw (1973) believe that financial liberalisation in the form of an appropriate rate of return on real cash balances is a vehicle of the rate of capital formation and promoting economic growth. According to this hypothesis, a low or negative real interest arte will discourage saving. This will reduce the availability of loanable funds for investment, which in turn lower the rate of economic growth. MckinnonShaw model posits that a more liberalised financial system will induce and increase in saving and investment and therefore, promote economic growth. Ahmed and Ansari (1995) investigated that Mckinnon and Shaw hypothesis for Bangladesh and found that weak support for their hypothesis. They focused more on the price variable as the relevant factors for economic growth. Khan and Hasan (1998) examined the Mckinnon-Shaw hypothesis for Pakistan and found strong support.

Greenwood and Jovanovic (1990) employ a general equilibrium approach and conclude that as saver gain onfidence in the ability of the financial intermediaries they place an increasing proportion of their savings with their intermediaries. Greenwood and Smith (1997) use two models with endogenous growth formation and examine the way banks and stock markets allocate funds to the highest value users. King and Levine (1993b) employ an endogenous growth model in which the financial intermediaries obtain information about the quality of individual projects that is not readily available to private investors and public markets. This information advantage enables financial intermediaries to fund innovative products and productive processes, thereby inducing economic growth [De La Fuente and Marin (1994)].

There is a considerable body empirical and theoretical literature that postulates a positive relationship between financial sector development and economic growth, using time series analysis. The results have been largely mixed. Jung (1986) used vector autoregressions (VARs) in levels on post-1960 
annual time series data for 56 countries, of which 19 are developed industrial economies, and found bi-directional causality between financial and real variables in most cases. Demetriades and Hussein (1996) conducted causality tests for 16 developing countries and find little evidence that financial sector development causes economic growth, though they did find many bi-directional relationships. They concluded that causality patterns varied across countries. They also find that there have been stable long-run relationships between real per capita income and at least one of the key financial indicators in 13 out of 16 countries, most of which have following financial reforms. In these long-run relationships, financial variable exerts positive impact on real per capita income. Rousseau and Wachtel (1998) applied VAR approach to five industrialised countries over the period 1870-1929 and found strong uni-directional link from finance to growth. They also estimated a vector error-correction model (VECM) for each country and found evidence of an economically important long-run relationship between the two sectors. Bell and Rousseau (2001) used this approach for post-independence India and found that financial intermediaries played a more emphatic role in promoting investment than in increasing total factor productivity, and interpreted this as evidence for the presence of a factor accumulation. Rousseau and Vuthipadadorn (2005) used time series approach to investigate whether the intensity of financial intermediaries promoted investment and growth in 10 Asian economies including Pakistan over the period 1950-2000. They used VAR and VECM to examine the nature of the causality between measures of financial and real sector activity. They find strong uni-directional causality from finance to investment in most cases, and weaker support for a casual link from finance to the level of output. These findings are consistent with a factor accumulation channel as the primary mechanism through which the financial sector influenced macroeconomic outcomes in these countries. Sinha and Macri (2001) have examined the relationship between financial development and economic growth using time series date for eight Asian countries including Pakistan over the period 1950-97. The regression results show a positive and significant relationship between the income and financial variable for India, Malaysia, Pakistan, and Sri Lanka. The multivariate causality tests show a two-way causality between income and financial variables for India and Malaysia, one-way causality from financial variables for Japan and Thailand, and reverse causality for Korea, Pakistan and Philippines. Thus, their results clearly support the general view of a positive relationship between financial development and economic growth.

Ghatak (1997) examines the impact of financial development on economic growth in Sri Lanka over the period 1950-87. He concludes that interest rates and financial deepening increase economic growth. Demetriades and Hussein (1996) explore the relationship between financial policies and economic growth for Nepal over the period 1962-92. The study concludes that real per capita income is positively associated with financial deepening and 
negatively with bank branches. The negative association between per capital income and bank branches reflects inefficiencies in financial intermediation for a given level of financial development. The authors also find that financial repression in the form of selective intervention has a positive impact on economic growth.

Fry (1997) find inverted U shaped relationship between the annual rate of economic growth and financial development measured by real interest rates. The results of this study imply that too high or too low real interest rates are deleterious for economic growth. The results also indicate that economic growth maximised when interest rates are within the range of -5 percent to +15 percent. Similarly, using the Chilean and Korean experience, Clark (1996) suggests that the equilibrium real interest rate is undefined and unstable, since the interest rate plays a dual role. In one hand, it equilibrates saving and investment, on the other hand, it determines portfolio readjustment, including capital inflows. Portfolio adjustment causes fluctuations in interest rates. These fluctuations are intensified by the uncertainty and volatility of expected returns to investment and potential inflows of capital, which may distort the real exchange rate and increase the cost of borrowing.

Arestis, et al. (2001) examine the relative impact of stock markets and banks on long-term economic growth in Germany, the USA, Japan, the UK and France. They find that both stock markets and banks have made important contributions to output growth in Germany, France and Japan, with the stock market's contribution ranging from about one-seventh to one-third of the bank's contribution. These results are consistent with the view that bank-based financial system may be more able to promote long-term growth than stock market-based. The authors further find that there is a weak relationship between financial development and economic growth in the UK and the USA. The results also suggest that stock market volatility has negatively affected economic growth in France and Japan.

Khan, et al. (2005) tested the relationship between financial development and economic growth for Pakistan over the period 1971-2004, using Autoregressive Distributed Lag (ARDL) technique. The results of the study suggest that in the long-run financial depth and real interest rate exerted positive impact on economic growth. However, the relationship between growth and financial development is though positive but remained insignificant in the shortrun. Their results suggest that growth is an outcome of financial development.

Chang and Ho (2000) studied the joint impact of trade and finance on economic growth for South Korea over the period 1953-99. Applying JohansenJuselius multivariate cointegration approach, the study finds the existence of single cointegrating vector among economic growth, financial development and the degree of openness. Through Granger causality tests based on error correction model, they found that causality running from financial development 
to economic growth and not the reverse. Hence, the study supports the supplyleading hypothesis for South Korea.

\subsection{Trade and Economic Growth}

The literature on trade liberalisation can be grouped into two categories. The first Category, examines export-growth nexus, while the second relates to the nexus between trade liberalis ation and growth using with and without and before and after approaches. However, there has been a great deal of controversy. Using cross-section data, Feder (1983), Balassa (1978), Tyler (1981) and Michaely (1973) have found positive association between exports and economic growth. However, the results of these studies involve a spurious correlation due to the fact that exports themselves being part of national product. This concern led to a version of cross-sectional studies, which estimate aggregate production function that includes exports as explanatory variable along with other proposed economic growth determining fundamentals such as labour, capital, and investment. ${ }^{3}$

The cross-country studies utilise different indicators of openness to examine the relationship between trade liberalisation and growth. The most important studies include Dollar (1992), Sachs and Warner (1995) and Edward (1998). Dollar (1992) used an index of real exchange rate distortions and an index of real exchange rate volatility as indicators of trade orientation. The results indicate that each indicator is negatively related to growth in a sample of 95 developing countries.

Sachs and Warner (1995) construct a binary index of openness to examine various aspects of trade policies including average tariff rates, nontariff barriers, and black market premium on exchange rates etc. According to this index, they find that countries that are more open enjoy higher growth rates. Yang and Huang (1997) suggest that a decline in the economy -wide tariff leads to more equitable distribution of income in China using a Computable General Equilibrium (CGE) model. Similarly, Edwards (1998) investigated that robustness of the openness-growth nexus by utilising different indicators of openness. He concluded that there is positive and significant association between trade openness and economic growth.

Greenaway, et al. (2002) analysed the relationship between trade liberalisation and growth rate of GDP for 73 developing countries. The analysis is based on three different measurements of liberalisation. Firstly, through nontariff barriers, average tariff, and black-market exchange rate premium. Secondly, through level of quotas, tariff, and export impediments and exchange rate misalignment. Lastly, with a dummy variable for the structural adjustment programme.

\footnotetext{
${ }^{3}$ For further detail, see Ram (1985), Balassa (1985), Michaelpoulos and Jay (1973).
} 
The empirical results of this study were obtained using ordinary least squares (OLS) technique with three different time period and three different indicators. The results for the short-run from the first two indicators showed the positive and significant impact of trade liberalisation on growth. The last indicator showed insignificant impact of trade liberalisation on growth. However, the results from all indicators showed that liberalisation affects the growth rate of GDP with a lag in the long-run.

Irwin, et al. (2002) examined the relationship between trade liberalisation and income growth for countries engaged in bilateral trade for different time periods. They utilised instrumental variable (IV) technique of estimation. The results of the study suggest that more liberal economies enjoy a higher level of per capita income. Yanikkaya (2003) utilised various measures of trade volumes and trade restrictions as alternative indicators of openness in a panel of 100 developed and developing countries. He finds a positive relationship between openness and economic growth when trade volumes are used as an indicator of openness. The study also finds a positive relationship between trade barrier and economic gro wth.

A very few studies have examined the impact of liberalisation on economic growth in the case of Pakistan. Khan, et al. (1995) examined the causality between exports and economic growth in Pakistan. The evidence of the study suggests that exports promote economic growth. Iqbal and Zahid (1998) investigated macroeconomic determinants of growth including trade openness. The results suggest the openness has a beneficial impact on economic growth. Mohsin, et al. (2001) examine the impact of impact of openness on poverty level in Pakistan for the period 1963-64 to 1993-94. The study demonstrates that poverty has declined in Pakistan with trade liberalisation. Kemal et al. (2002) tested the relationship between exports and economic growth in South Asian Countries including Pakistan. They find a positive association between exports and economic growth for all countries. Din, et al. (2003) examined the link between economic growth and openness for Pakistan over the period 1960-2001. The analysis is based on the Engle and Granger (1987) two-step cointegration technique and error correction models (ECM) are used to determine the short-run causality between growth and openness. The results indicate the there is significant long-run relation between economic growth and openness. However, there is no evidence of short-run causality between economic growth and openness and vice versa. Since Granger causality is based on the statistical property of the data and not on the structural relationships implied by economic theory. Furthermore, there is variety of economic, institutional and political factors influencing economic growth. They recommended that multivariate model might be more appropriate to examine the relationship between economic growth and openness. 
Though there are several studies on this issue. Studies regarding Pakistan are very less. Therefore, it is felt necessary to study such relationship. This study receives special importance to have an idea whether the financial development and trade liberalisation causes economic growth in the context of Pakistan or the reverse case. It is well-known fact that economy of Pakistan has undergone severe changes since independence. Though the economy of Pakistan is basically Agrobased, but over the period wider industrial development has been taken place. There is also widespread financial sector development, which has taken place, especially after the globalisation and liberalisation policy of 1990s. During this period there has been a significant improvement in the growth rate of the economy. The economy is also growth at a reasonable rate along with the financial sector development. This growth and development has very important implications on the external sector. Although, Pakistan is a small open economy, but is an important player in international market in terms of exports and imports, which significantly affect the economic growth and financial sector development. Keeping the importance of both trade and finance in economic development, it is felt necessary to study and test the hypothesis that both trade and finance enhance economic growth in the country and try to find whether financial development and trade liberalisation causes economic growth or vice versa.

\section{OVERVIEW OF THE FINANCIAL AND TRADE POLICIES IN PAKISTAN}

Economic growth of developing countries is heavily based on the financial sector's credit allocation. Overall financial development is necessary for economic growth at the macro-level [Andersen and Tarp (2003); Khan and Senhadji (2000); Levine (2002)]. A more advanced intermediation enables firms to raise and manage large amount of funds more effectively, resulting in a rapid economic development. Particularly, the development of financial sector is an important for developing countries because bank-based system has greater impact on growth at the early stage than does a market-oriented system [Fase and Abma (2003); Tadesse (2002); Iimi (2004)]. This section briefly reviews the financial and trade liberalisation policies pursued by the government $\mathrm{b}$ enhance growth.

\subsection{Financial Sector Reforms}

In Pakistan, the banking sector reforms were initiated under broader macroeconomic structural adjustment programmes in the early 1990s. Through these reforms, the government has been aiming to make the financial industry more competitive and transparent by privatising formerly nationalised commercial banks, liberalising interest rates and credit ceilings, strengthening the supervisory capacity of central bank and standardised accounting and auditing systems [Iimi (2004)]. 
Prior to the 1990s, the financial sector in Pakistan remained heavily controlled. ${ }^{4}$ Interest rates were set administratively and were usually remained negative in real terms. Monetary policy was conducted primarily through direct allocation of credit. Money market was under-developed, and bond and equity markets were virtually nonexistent. Commercial banks often had to lend priority sectors with little concern for the borrowing firm's profitability. Despite the opening of non-bank financial sector for private investment in mid-1980s, stateowned financial institutions hold almost 93.8 percent of the total assets of the entire financial sector at the end of 1980s. Moreover, the status of financial institutions were precarious due to, inter alia, high intermediation costs resulting from overstaffing, large number of loss-incurring branches, poor governance with low quality banking services, accumulation of non-performing loans and inadequate market capitalisation. These inefficiencies and distortions caused severe macroeconomic difficulties in the late 1970s and 1980s. In order to remove these distortions and spur economic growth, the government of Pakistan undertook a wide range of reforms in the early 1990s to strengthen its financial system and to provide an adequate macroeconomic environment.

The objectives of these reforms were to prepare industrial conditions for market competition, strengthening corporate governance and supervision, and adopting a market-based indirect system of monetary, exchange and credit management. In the first phase of financial reforms ${ }^{5}$, the government liberalises the market entry of private and foreign banks ${ }^{6}$ in order to gain efficiency and enhance competition within the financial sector. Secondly, small-nationalised banks, such as MCB and ABL, were partially privatised. Thirdly, major stateowned commercial banks and DFIs were downsized in terms of branches and employees. Fourthly, credit ceiling as an instrument of credit control was abolished, credit-deposit ratio (CDR) was also abolished and open market operation is now instrument of monetary policy and SBP at regular intervals conducted auctions of government securities. Fifthly, loan recovery process was strengthened by establishing banking courts and standardising loan classification and accounting rules. Finally, State Bank of Pakistan (SBP) was granted full autonomy.

Despite these efforts of financial liberalisation, financial markets segmentation continued owning continuing controls on interest rates on government debts and to specialised credit programmes. As a result, the second

\footnotetext{
${ }^{4}$ All commercial banks were nationalised in January, 1974, with the aim at making credit availability to highly priority sectors of the economy which previously had limited access to investable funds [see Haque and Kardar (1993) for detailed account].

${ }^{5}$ The early phase of financial reforms started in the late 1980s to earlier 1990s.

${ }^{6} 10$ new private banks started their operations in 1991 and 23 private domestic banks operating in the country including HBL, ABL, MCB and UBL. The process of liberalisation started in the early 1990s and except NBP more than 50 percent shares of the public sector have been privatised. There are about 14 foreign banks have been operating in the country.
} 
phase of banking sector reforms ${ }^{7}$ was introduced in 1997. These reforms addressed the fundamental causes of crisis and corruption and strengthen the corporate governance and financial discipline. In this regard, the cost structure of banks was firstly restructured through capital maintenance and increased by public funds. Secondly, partially privatised commercial banks were privatised completely. Third, bank branches were fully libera lised and allow private banks to grow faster and increase their market share. Fourthly, loan collateral foreclosure was facilitated and strengthened to reduce default costs and to expand lending to lower tier markets, including consumer banking. Fifthly, national savings schemes were reformed so as to integrate with the financial market. Sixthly, mandatory placement of foreign currency deposits was withdrawn. Lastly, Strengthened SBP to play more effective role as regulator and guardian of the banking sector and phase out the direct and concessional credit programmes to promote market integration.

To promote intermediation and to attract funds held abroad by Pakistani nationals, the resident Pakistanis were allowed to open foreign currency accounts (FCAs), which were freely transferable abroad. These accounts were exempted from income and wealth tax, and no question was to be asked about the source of foreign exchange. Persons holding FCAs could also obtain rupee loans against such accounts.

To facilitate the flow of sufficient short- term liquidity at variable rate it was necessary to expand the money market potential by making it accessible to new operators. Particularly, to those who were experiencing an excess of liquidity, such as insurance companies, mic rofinance institutions, SME bank as well as investment banks. This widening the range of operators on the money market by the creation of new financial products, such as deposit certificates, treasury bills and bonds, which are naturally negotiable.

\subsubsection{Impact of financial Reforms}

The object of the financial and operational reform policies was to strengthen the microeconomic foundations of the banking system. However, the pace of deposit mobilisation remained slow and the reforms were partially effective [Khan (2003)]. Generally, financial sector developments include: ${ }^{8}$ (1) Financial deepening, which consists of the growth of financial instruments commonly measured by the ratio of monetary aggregates to GDP. (2) Financial broadening, which implies an increase in the number of financial institutions, financial transactions through cheques, and financial instruments. (3) Financial liberalisation, which indicates deregulation of interest rates, free movement of foreign capital, and removal of other restrictions.

\footnotetext{
${ }^{7}$ The second phase of banking sector reforms started from 1997 to 2001.

${ }^{8}$ See for example Ansari (2002), p.79.
} 
After liberalisation, the price of financial services was intended to be determined by the banks on competitive basis, with little intervention from the SBP. To achieve the twin objectives of reducing government cost of borrowing on domestic debt and encouraging private sector credit expansion, the SBP has been pursuing a relatively easy monetary policy since July 1995 to July 2000. The weighted average lending rate gradually come down from 15.6 percent in 1998 to $8.81^{9}$ percent in June 2005, but the real interest rate has increased from 3.6 percent in 1996 to 10.9 percent in 2000 and then following the declining trend and reached to -0.49 percent in June 2005 (see Table 1). This reduction in lending rate indicates a little improvement in the profitability of the banks but purely ad hoc and not in the lines of the liberalisation. Similarly, the weighted average deposit rate reduced from 6.8 percent in 1998 to 1.37 percent in June 2005; the real deposit rate remained negative except for the period 1999-2002. This reduction in the deposit rate will reduce the savings even further.

Table 1

Interest Rate Behaviour in Pakistan

\begin{tabular}{|c|c|c|c|c|c|c|c|}
\hline \multirow[b]{2}{*}{ Year } & \multirow[b]{2}{*}{ Inflation Rate } & \multicolumn{2}{|c|}{$\begin{array}{l}\text { Weighted average } \\
\text { Lending Rate } \\
\end{array}$} & \multicolumn{2}{|c|}{$\begin{array}{c}\text { Weighted Average } \\
\text { Deposit Rate } \\
\end{array}$} & \multicolumn{2}{|c|}{$\begin{array}{c}\text { Interest Rate } \\
\text { Spread } \\
\end{array}$} \\
\hline & & Nominal & $\overline{\text { Real }}$ & Nominal & $\overline{\text { Real }}$ & Nominal & Real \\
\hline $1990-95$ & 10.57 & 12.55 & 1.98 & 6.53 & -4.05 & 6.02 & 5.95 \\
\hline 1996 & 10.8 & 14.4 & 3.6 & 6.4 & -4.4 & 8.00 & 8.00 \\
\hline 1997 & 11.8 & 14.6 & 2.8 & 6.8 & -5.0 & 7.8 & 7.8 \\
\hline 1998 & 7.8 & 15.6 & 7.8 & 6.8 & -1.0 & 8.8 & 8.8 \\
\hline 1999 & 5.7 & 14.8 & 9.1 & 6.5 & 0.8 & 8.3 & 8.3 \\
\hline 2000 & 3.6 & 13.52 & 10.9 & 5.47 & 1.9 & 8.05 & 9.00 \\
\hline 2001 & 4.4 & 13.61 & 9.21 & 5.27 & 0.87 & 8.34 & 8.34 \\
\hline 2002 & 3.5 & 13.19 & 9.69 & 3.61 & 0.11 & 9.58 & 9.58 \\
\hline 2003 & 3.1 & 9.40 & 6.3 & 1.61 & -1.49 & 7.79 & 7.79 \\
\hline 2004 & 4.6 & 7.28 & 2.68 & 0.95 & -3.65 & 6.33 & 6.33 \\
\hline 2005 & 9.3 & 8.81 & -0.49 & 1.37 & -7.93 & 7.44 & 7.44 \\
\hline
\end{tabular}

Source: SBP Annual Reports (Various Issues).

The interest rate $\operatorname{spread}^{10}$ is an important indicator for the financial sector's competitiveness and profitability. Spread typically declined when competition among banks increases to access the financial market to increase their customer's base. But in Pakistan, the high lending rate and low deposit rate have generated large spread ${ }^{11}$ nearing 7.44 percent in June 2005 as against 6.33 percent in 2004. The high lending rate will increase the cost of borrowing and

\footnotetext{
${ }^{9}$ Although in 2004 the rate fell to 7.28 percent.

${ }^{10}$ Interest Rate Spread = (Average Lending Rate - Average Deposit Rate $)$.

${ }^{11}$ High interest rate spread is generated by factors such as high administrative costs, overstaffing and unavoidable burden of non-performing loans (for further detail, SBP's financial sector assessment 2003-2004).
} 
hence discourage investment. The low deposit rates discourage both consumption and savings, resulting high debt/GDP ratio, deterioration of banks balance sheet, lowering economic growth, and increase in poverty. Furthermore, the large spread also reflects perceived sovereign risk [Khan (2003)]. Hence, measures should be taken to bring down the interest rate spread close to zero in order to enhance both savings, investment in the country.

To measure the improvement in the financial sector following the financial reforms process, the standard indicators used in this study include the ratios of M2/GDP, BDL/GDP, MCH/GDP, PSC/GDP, SMC/GDP, CC/M2 and CC/GDP. ${ }^{12}$ Table 2 represents the entire situation regarding the financial sector of Pakistan. Table 2 shows that the ratio of $\mathrm{M}_{2} / \mathrm{GDP}$ increased steadily. It should be noted that a large ratio of $\mathrm{M}_{2} / \mathrm{GDP}$ represents a more developed and efficient financial sector. In 1990 the average monetary assets were around 32.27 percent of GDP, while it was reached to 49.4 percent of the GDP in 2004 and slightly come down to 48.6 percent of the GDP in 2005 because the other instruments outside the $\mathrm{M}_{2}$ become available. ${ }^{13}$ Since $\mathrm{M}_{2}$ is more saving-investment oriented and the steady growth in $\mathrm{M}_{2} / \mathrm{GDP}$ caused positive impact on economic growth. However, $\mathrm{M}_{2} / \mathrm{GDP}$ recorded gradual growth, showing an improvement in the financial sector. The ratio of bank deposit liabilities to GDP assesses the degree of monetisation in the economy. A steady growth in this ratio over the period of study also indicates an improvement in the financial sector. Similarly the amount of money clear by banks through cheques relative to GDP increases gradually also showing an improvement of financial services offered of financial institutions. Figure 1 depicted the trend behavior of each financial indicator.

The ratio of private sector credit to GDP indicates an efficient allocation of funds by the banking sector. Even though this ratio has been increasing gradually over the years, there is ample room for further growth given the recent privatisation of the large public sector commercial enterprises. The other tools of financial development include currency to M2 ratio and currency to GDP ratio reflecting the increase in total deposits relative to currency in circulation and degree of monetisation in the economy, which was 23 percent and 11.18 percent of the GDP in 2005 respectively. The stock market capitalisation, which was 4.68 percent of GDP in 1990, is now 30.95 percent of GDP in 2005.

\footnotetext{
${ }^{12} \mathrm{M} 2 / \mathrm{GDP}, \mathrm{BDL} / \mathrm{GDP}, \mathrm{MCH} / \mathrm{GDP}, \mathrm{PSC} / \mathrm{GDP}, \mathrm{SMC} / \mathrm{GDP}, \mathrm{CC} / \mathrm{GDP}$ are respectively ratio of broad money (currency+demand deposits+time deposits+foreign currency accounts) to gross domestic product, ratio of bank deposit liabilities to gross domestic product, ratio of money cleared through clearing house to gross domestic product, ratio of private sector aredit to gross domestic product, ratio of stock market, capitalisation to gross domestic product, and currency in circulation to gross domestic product.

${ }^{13}$ This is due to the lack of access to the banking system, the use of credit as means of payments etc. As financial liberalisation began and other financial instruments were developed, this ratio tends to decline [Khan (2003)].
} 
Table 2

Indicators of Financial Deepening (in percent)

\begin{tabular}{|c|c|c|c|c|c|c|c|c|c|c|}
\hline Indicators & $1961-70$ & $1971-80$ & $1981-90$ & 1990 & 2000 & 2001 & 2002 & 2003 & 2004 & 2005 \\
\hline Total Bank Deposit iabilities/GDP ${ }^{2}$ & 23.52 & 34.47 & 32.36 & 27.91 & 37.51 & 33.23 & 36.03 & 40.32 & 44.16 & 45.02 \\
\hline Amount of clearing house/GDP* & 90.74 & 97.70 & 111.63 & 126.88 & 141.23 & 138.68 & 152.48 & 182.72 & 213.26 & 248.26 \\
\hline Currency/M $\mathrm{M}_{2}$ & 45.13 & 32.29 & 32.28 & 37.56 & 27.80 & 26.02 & 25.30 & 25.04 & 23.99 & 23.00 \\
\hline Currency/GDP & 16.06 & 13.53 & 13.29 & 14.73 & 10.82 & 10.31 & 11.08 & 11.77 & 11.84 & 11.18 \\
\hline Stock Market Capitalisation/GDP & 8.42 & 4.08 & 3.75 & 4.68 & 10.24 & 8.15 & 9.26 & 15.48 & 24.05 & 30.95 \\
\hline
\end{tabular}

Note: ${ }^{1}$ Broad money (money + quasi money). Broad money includes the sum of currency outside the banks plus demand, time, savings and foreign currency deposits of residents other than the central government.

${ }^{2}$ Total Bank Deposit Liabilities are equal to liquid liabilities minus currency in circulation. Demetriades and Luintel (1996) argue that without deducting

currency in circulation, we are left with primarily a measure of monetisation, not financial depth (p.360).

* The amount of money cleared through cheques by the clearing house can also be used as an indicator of financial services development. 
Fig. 1. Financial Development Indicator Relative to GDP

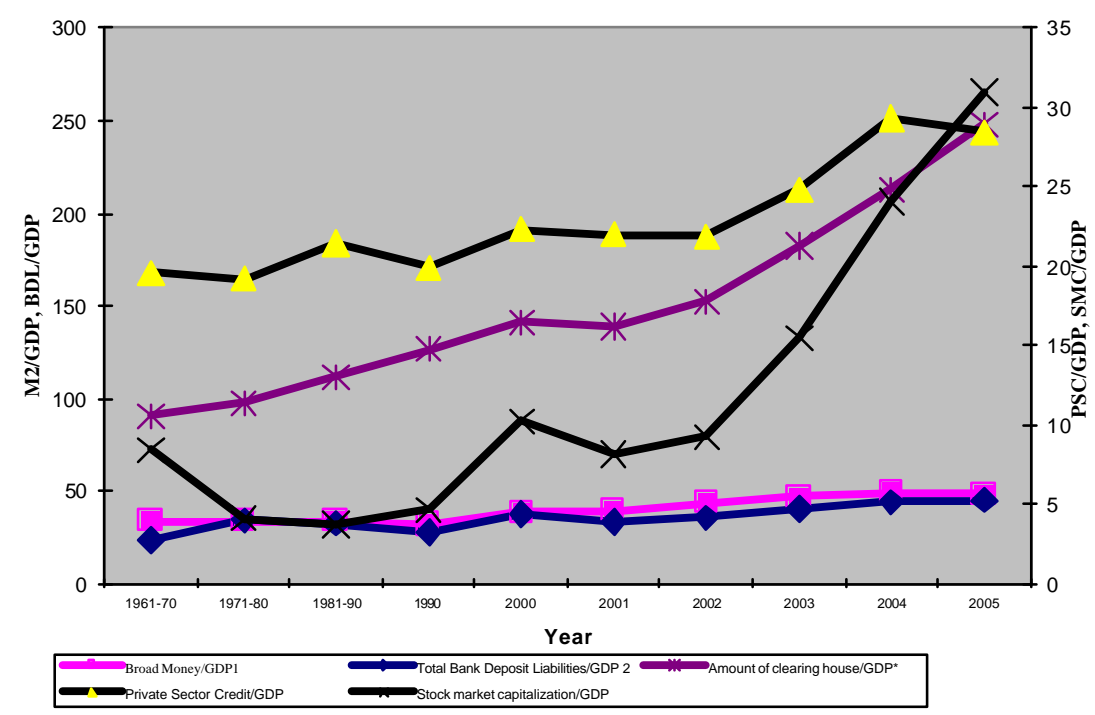

\subsection{Trade Liberalisation}

Pakistan has pursued a mixed economy approach to development following import substitution industrialisation policies in order to: (i) strengthen the industrial base (ii) achieve self reliance, (iii) protect domestic infant industries, (iv) insulate the domestic economy into external shocks stemming from international capital markets, and (v) reduce the chronic balance of payments deficits and use scarce foreign exchange resources.

To achieve these objectives, the government imposed various quantitative and qualitative restrictions on trade to protect domestic industries. During the 1960s a more liberal policies being opted by the government where the private sector was encourage to play a greater role. ${ }^{14}$ Consequently, both industrial production and exports registered a reasonable increase during this period. However, this trend was reversed during 1970s because of nationalisation of industries, financial institutions and an increasing domination of public sector in the economic activities. Although, the government took various measures such as, devaluation of Pak-rupee vis-à-vis US-dollar, elimination of export bonus scheme and discontinuation of restrictive import licensing scheme to boost exports. But these steps do mt register any significant impacts on exports.

\footnotetext{
${ }^{14}$ Although highly protected trade regime remained effective in this period. However, some additional policies such as, an overvalued exchange rate, export bonuses, preferential credit access to industries with export potential and automatic renewal of import licenses, were introduced to encourage exports [Yasmin, et al. (2006)].
} 
In the late 1980s, Pakistan was faced with high macroeconomic imbalances as a result of the growing inefficiency and losses in the public sector. To restore the business confidence and to reduce inefficiency and losses in the public sector, the government implemented a wide range of structural and institutional reforms in the early 1990s. The most specific measure undertaken by the government includes:

- Reduction of maximum tariff rate on imports from 225 percent in 198687 to 25 percent in 2005 [Husain (2005); Kemal (2001) and Anwar (2002)]. The average tariff rate has come down to 11 percent as compared to 65 percent a decade earlier [Husain (2005)]. Similarly, the number of custom duty slabs was reduced from 13 in 1996-97 to 4.

- Quantitative import restrictions were lifted except those relating to security, health, and public morals, religious and cultural related.

- All para-tariffs have been merged in to the statutory tariff regime, and import duties on 4000 items were reduced.

These measures have brought down effective rate of protection, eliminate the anti-export bias and promote competitive and efficient industries. A number of laws ${ }^{15}$ were also been promulgated to bring the trade regime in line with WTO regulations.

Despite the substantial reduction in tariff rate, removal of all non-tariff barriers and successive devaluation of the currency, ${ }^{16}$ the growth in exports in the 1990s was only 5.6 percent per annum as compared to 14.97 percent in the 1970s and 8.5 percent in the 1980s (see Table 3 and Figure 2). However, the overall trade to GDP ratio has risen from 26.31 percent in 1970 s to 37.65 percent today in Pakistan. This gives an indication of higher level of trade integration

In order to encourage foreign direct investment, restrictions on capital inflows and outflows were gradually lifted. Investors were also allowed to purchase up to 100 percent of the equity in industrial companies on repatriable basis without any prior approval. Furthermore, investment shares issued to non-residents could be exported and remittance of dividend and disinvestments proceeds was permissible without any prior permission of SBP. In 1994, restrictions on some capital transactions were partially relaxed, and foreign borrowing and certain outward investments were allowed to some extent. Full convertibility of the Pak-rupee was established on current international transactions. The establishment of an interbank foreign exchange market also marked an important step towards decentralising the management of foreign exchange and allowing market forces to play a greater role in exchange rate determination.

\footnotetext{
${ }^{15}$ Such as antidumping, countervailing measures and intellectual property rights.

${ }^{16}$ The average annual depreciation of exchange rate was about 10 percent in the 1990 s (i.e. Rs 24 in 1990 to Rs 60 in 2000).
} 
Table 3

Growth Rates of Exports and Imports and Degree of Openness (in percent)

\begin{tabular}{lrrrrrrrrr}
\hline Year & $1961-70$ & $1971-80$ & $1981-90$ & $1991-00$ & 2001 & \multicolumn{1}{c}{2002} & 2003 & 2004 & \multicolumn{1}{c}{2005} \\
\hline Exports (\$) & 6.07 & 14.97 & 8.52 & 5.61 & 9.07 & 2.32 & 19.14 & 13.84 & 15.93 \\
Imports (\$) & 8.35 & 18.78 & 4.54 & 3.22 & 6.25 & -7.53 & 20.13 & 20.04 & 37.64 \\
(X+M)/GDP & 18.28 & 26.31 & 29.93 & 32.90 & 28.91 & 28.68 & 29.89 & 32.99 & 37.65 \\
\hline Source: State Bank of Pakistan (Handbook of Pakistan Economy, 2005).
\end{tabular}

Fig. 2. Exports, Imports, and Degree of Openness (in percent)

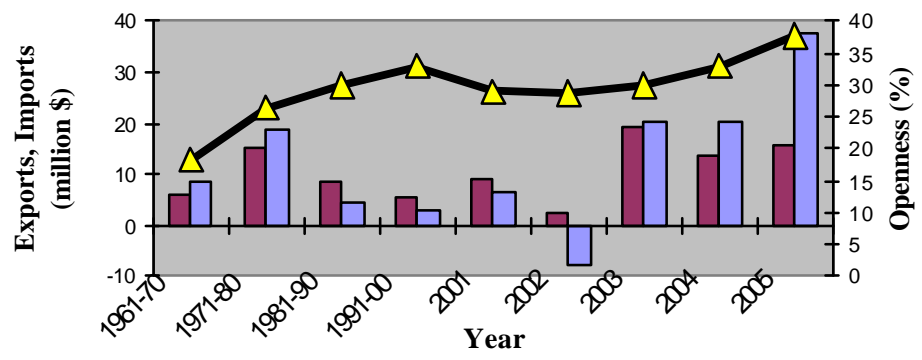

$$
\square \text { Exports (\$) } \square \text { Imports (\$) } \square(\mathrm{X}+\mathrm{M}) / \mathrm{GDP}
$$

\section{MODEL SPECIFICATION, METHODOLOGY AND DATA ISSUES}

Theoretical literature predicts that real income; financial development and real interest rate are positively correlated. The positive relationship between the level of output and financial development resulted from the complementarity between money and capital [Mckinnon (1973)]. Furthermore, the removal of ceilings on deposit rate results in positive real interest rate, which increase savings and hence economic growth. King and Levine (1993, 1993a) predict a positive relationship between real income, financial development and real interest rate.

Based on these theoretical postulates, the relationship between real output and financial development can be specified as:

$$
L R G D P_{t}=\alpha_{0}+\alpha_{1} L F S D_{t}+\alpha_{2} R D R_{t}+\varepsilon_{t} \quad \ldots \quad \ldots
$$

Where $R G D P$ is real output, FSD is the financial sector development, $R D R$ is the real deposit rate and $\varepsilon$ is an error term. Except real deposit rate, all the variables are expressed in logarithmic form. 
Theoretical and empirical research indicates a strong and positive correlation between trade liberalisation and economic growth over long period of time. Sachs and Warner (1995) has pointed out that open economies has grown about 2.5 percent faster than closed economies and the difference is larger among developing countries. Jin (2000) argued that trade liberalisation and openness has provided an important base of economic activity. Thus, an increasing openness is expected to have a positive impact on economic growth. ${ }^{17}$ Barro (1991) provided evidence that increasing openness had a positive effect on GDP growth per capita. Edwards (1992) also found a positive and significant effect of openness on GDP growth. It can be argued that through the openness countries are able to benefit from information spillovers such as scientific advances and improvements. Sukar and Ramakrishna (2002) argued that countries that liberalise their external sector and reduce impediments to international trade could experience relatively higher economic growth. Thus, we extend Equation (1) by incorporating the variable TOPEN which capture the impact of trade liberalisation on real output. Now Equation (1) can be written as:

$$
L R G D P_{t}=\alpha_{0}+\alpha_{1} L F S D_{t}+\alpha_{2} R D R_{t}+\alpha_{4} L T O P E N+\varepsilon_{t} \quad \ldots
$$

To examine the long run relationship between real GDP, trade liberalisation, financial development, and real deposit rate, we employ bound testing approach to cointegration within the framework of Autoregressive Distributed Lag (ARDL) developed by Pesaran, et al. (2001). There are several reasons for the use of bound test. Firstly, the bivariate cointegration test introduced by Engle and Granger (1987) and the multivariate cointegration technique proposed by Stock and Watson (1988), Johansen $(1988,1991)$ and Johansen and Juselius (1990) are more appropriate for large sample size. While the bound testing procedure of cointegration is more appropriate for a small sample size [Pesaran, et al. (2001); Tang (2001, 2002)]. Secondly, bound testing approach avoids the pre-testing of unit roots. Thirdly, the long run and short run parameters of the model are estimated simultaneously to tackle the problem of endogeneity and simultaneity. Fourth, all the variables are assumed to be endogenous. Finally, this method does not require that the variables in a time series regression equation are integrated of order one. Bound test could be implemented regardless of whether the underlying variables are I (0), I (1), or fractionally integrated.

\footnotetext{
${ }^{17}$ More recent studies after the Asian Economic Crisis of 1997-99, have challenged some of these findings. Rodrigues and Rodrik (1999) have raised question about measuring the degree of openness, and have identified many other factors that affect growth. They concluded that trade liberalisation does always leads to higher growth. Batra (1992), Batra and Slottje (1993) and Leamer (1995) concluded that freer trade is the primary source of economic downturns.
} 
An ARDL $(p, q)$ model of Equation (2) in the form of unrestricted errorcorrection can be formulated as:

$$
\Delta Y_{t}=\sum_{j=1}^{p-1} \gamma_{j} \Delta Y_{t-j}+\sum_{j=0}^{p-1} \delta_{j} \Delta X_{t-j}+\varphi\left[Y_{t-1}-\left\{\beta_{0}+\beta_{1} X_{t-1}\right\}\right]+\varepsilon_{t} \quad \ldots
$$

Where $Y$ is the growth of real GDP and $X$ is a vector of explanatory variables (i.e. $L F S D, R D R, L T O P R N), \gamma$ and $\delta$ are the short-run coefficients related to growth and its determinant, $\beta$ are the long-run coefficients, $\varphi$ is the speed of adjustment to the long-run relationship, and $\varepsilon$ is error term. The term in square brackets contains the long-run relationship, which acts as forcing equilibrium condition:

$$
Y_{t}=\beta_{0}+\beta_{1} X_{t}+u_{t} \quad \text { where } u_{t} \sim I(0) \quad \ldots \quad \ldots
$$

For the presence of a long run relationship amongst the variables of equation (2) is tested by means of bounds testing procedure proposed by Pesaran, et al. (2001). The bounds testing procedure is based on the $F$-stat (or Wald statistics) for cointegration analysis. The asymptotic distribution of the $F$-statistic is nonstandard under the null hypothesis of no cointegration between the examined variables, irrespective of whether the explanatory variables are purely I (0) or I (1). To implement the bound test, the null hypothesis is tested by considering the unrestricted error correction model (UECM) for real GDP in Equation (2) and a joint significance test was performed as:

$$
\begin{aligned}
& H_{0}: \beta_{0}=\beta_{1}=\beta_{2}=0, \\
& H_{1}: \beta_{0} \neq \beta_{1} \neq \beta_{2} \neq 0 .
\end{aligned}
$$

Pesaran, et al. computed two sets of critical values for a given significance level. One set assumes that all variables are I (0) and other set assumes that they are all I (1). If the computed $F$-statistic exceeds the upper critical bounds value, then the $H_{0}$ is rejected. If the $F$-statistic falls into the bounds then the test becomes inconclusive. If the $F$-statistic lies below the lower critical bounds value, it implies no cointegration. ${ }^{18}$

Once the long run relationship is identified, then the long run and shortrun estimates of the ARDL model can be obtained from Equation (3). At the second stage of ARDL cointegration method, it is also possible to perform a parameter stability test for the appropriately selected ARDL representation of the UECM. A general error correction representation of Equation (3) can be formulated as follows:

${ }^{18}$ This is similar to the Johansen and Juselius multivariate cointegration procedure, which has five alternative cases for long run. 


$$
\begin{array}{r}
\Delta L R G D P_{t}=\beta_{0}+\sum_{i=1}^{k} \beta_{1 i} \Delta L R G D P_{t-i}+\sum_{i=0}^{k} \beta_{2 i} \Delta L F S D_{t-i}+\sum_{i=0}^{k} \beta_{3 i} \Delta R D R_{t-i} \\
+\sum_{i=0}^{k} \beta_{4 i} \Delta L T O P E N_{t-i}+\lambda E C_{t-1}+\eta_{t}
\end{array}
$$

Where $\lambda$ is the speed of adjustment and $E C$ is the error-correction term obtained from the estimated cointegration model of Equations (2).

\subsection{Data Description}

The present study is based on the annual data covering the period from 1961-2005. The recent literature on financial development suggests several indicators used as proxy for the ability of financial intermediation. But in this study we basically calculated four financial development (FD) indicators related to banking and stock market. Firstly, total bank deposit liabilities relative to GDP which is calculated by taking the difference between liquid liabilities of the financial system minus currency in circulation divided by GDP. ${ }^{19}$ This considered the broadest measure of the financial intermediation. Secondly, ratio of private sector credit to GDP, which measures how much intermediation, is performed by the banking system. Third, amount of money cleared through clearing house relative to GDP. Lastly, the ratio of stock market capitalisation to GDP is calculated as the stock market capitalisation divided by GDP.

But the problem is that each indicator of financial development exerted different impact on real GDP and the derived coefficients may be biased. To avoid this problem, and following Kelly and Mavrotas (2003) we use total bank deposit liabilities ratio, value of clearing house ratio, credit allocation to private sector ratio and stock market capitalisation ratio, to construct financial sector development index (FSDI). We used FSDI as a proxy of government financial policy.

Real GDP is obtained as a ratio of nominal $\mathrm{GDP}^{20}$ to consumer price index (CPI 2000=100). Data on these variables are taken from IFS CD-ROM. The variable trade openness relative to GDP (TOPEN) is calculated by taking the ratio of sum of exports and imports to GDP. Data on exports, imports and deposit rate (DR) are taken from Handbook of Pakistan's Economy published by State Bank of Pakistan (2005). Inflation is calculated as a percentage by taking the log-difference of CPI, while real deposit rate is calculated by taking the difference between deposit rate and inflation rate.

\footnotetext{
${ }^{19}$ The standard measure of financial development is the ratio of M2 to GDP [World Bank (1989)]. However, this ratio measures the extent of monetisation rather than financial development. In developing countries, monetisation can be increasing without financial development; therefore, M2/GDP is not a satisfactory indicator of financial development. Therefore, we define ratio total bank deposit liabilities to GDP as proxy of financial development.

${ }^{20}$ Nominal GDP is adjusted for 1999-00 base.
} 


\subsection{Construction of Financial Development Index (FSDI)}

Measuring financial development is very complex and complicated process because there is no clear-cut definition as to what financial development is. Bandiera, et al. (2000) argued that an ideal index of financial sector development should include various aspects of regulatory and institutional reforms. However, measuring this aspect of government policy is very difficult if not possible task [Kelly and Mavrotas (2003)]. Inclusion all the policy variables separately in the same model cause serious estimation problems such as, multicolinearity etc. In order of avoid these problems, we use four different types of financial development indicators to construct the financial sector development index by using principal component method. ${ }^{21}$ These indicators include the ratio of total bank deposit liabilities to GDP which give an indication of the absolute size of the financial institutions, the ratio of clearing house amount to GDP which indicate the wide spread provision of financial services, the ratio of the private credit to GDP which measures the activities of the financial intermediaries and the ratio of the stock market capitalisation to GDP. The index represents a particular government financial policy variable. The financial development index also indicates a steady improvement in the financial sector (see Table 4 and Figure 3).

Table 4

Financial Sector Development Index (FSDI)

\begin{tabular}{lcccccccccc}
\hline Year & $1961-70$ & $1971-80$ & $1981-90$ & 1990 & 2000 & 2001 & 2002 & 2003 & 2004 & 2005 \\
\hline FSDI & 68.57 & 66.14 & 73.55 & 78.29 & 105.29 & 104.28 & 114.11 & 135.87 & 156.17 & 179.23 \\
\hline Source: Author's calculation based on IFS and State Bank of Pakistan's data.
\end{tabular}

Source: Author's calculation based on IFS and State Bank of Pakistan's data.

Fig. 3. Financial Sector Development Index (FSDI)

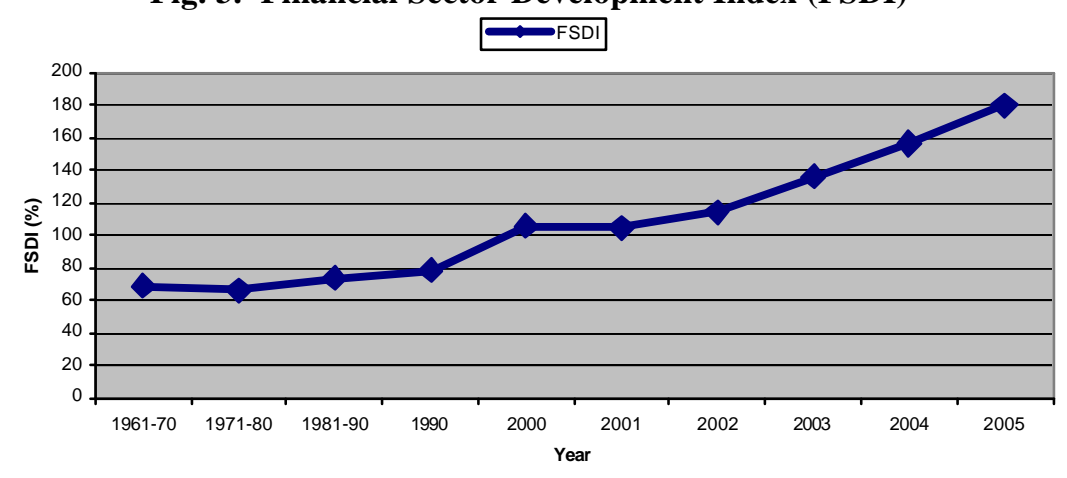

${ }^{21}$ The method of principal components is discussed in detail in Theil (1971). 


\section{EMPIRICAL RESULTS}

Two-step ARDL cointegration procedure is implemented in estimation of Equation (2) for Pakistan using annual observations over the period 1961-2005. In the first stage, the order of lags on the first-differenced variables for Equation (3) is obtained from UECM by mean of Schwarz Bayesian Criterion (SBC). ${ }^{22}$ The SBC gives a more parsimonious number of lags than other criteria such as Akaike Information Criterion (AIC). ${ }^{23}$ Given the limited number of observations, we experimented up to 2 lags on the first-difference and computed $F$-statistics for the joint significance of lagged levels of variables in Equation (3). The computed $F$-test statistic for each order of lags is presented in Table 5.

Table 5

Statistics for Selecting Lag Order and the Existence of Long-run Relationship

\begin{tabular}{lcccc}
\hline No. of Lag & AIC & SBC & CHSQSC $(1)$ & F-statistic \\
\hline 1 & 97.6794 & 87.9928 & 0.2184 & $28.2522^{*}$ \\
2 & 97.3983 & 86.9723 & 0.0811 & $31.4732 *$ \\
\hline
\end{tabular}

*Indicate significant at the 1 percent level of significance.

Based on the minimum value of SBC, the lag length of order 2 is selected for each series. When 2 lags are imposed, there exists a long-run relationship between LRGDP, LFSDI, RDR and LTOPEN because the calculated $F$-statistic (31.4732) is greater than the critical values of the upper level of the bound (i.e. 5.83 ) at the 5 percent level of significance. This result gives strong indication of cointegration among the variables included in Equation (2). ${ }^{24}$

Given the existence of a long run relationship, in the next step we used the ARDL cointegration method to estimate the parameters of Equation (2) with maximum order of lag set to 2 based on SBC. The long run results of Equation (2) based on SBC are reported in panel A of Table 6. The diagnostic test results of Equation (2) based on short run estimates are displayed in panel B of Table 6.

The empirical results presented in Table 6 indicate that the estimates possessed expected signs and are statistically significant at the 1 percent level of significance. The overall results are in accordance with the prediction that trade and financial policies have a positive impact on real GDP. These results also imply that liberalisation policies enhance economic growth rather than growth inducing liberalisation. The contribution of financial policy is more than the

\footnotetext{
${ }^{22}$ Bahmani-Oskooee and Bohl (2000) and Bahmani-Oskooee and Ng (2002) argued that the results of this stage are sensitive to the order of VAR.

${ }^{23}$ See Bernstein (2000).

${ }^{24} \mathrm{At}$ lag 2, the residuals are white noise as indicated by the Lagrange Multiplier test of serial correlation. i.e. $C H S Q_{S C(1)}$.
} 
trade policy to development, which is consistent with the fact that financial liberalisation facilitates trade liberalisation.

The study also found a positive and significant impact of FSDI and RDR on real GDP. This positive impact supports the prediction of Mckinnon and Shaw hypothesis that an increase in real interest rate facilitates financial savings and real income. Moreover, an acceleration of financial development raises the capacity of financial intermediaries to supply funds, which help to enhance investment and economic growth. These results are also in the lines with King and Levine (1993, 1993a), Levine, et al. (2000), Beck, et al. (2000), Levine (1999) and Khan and Senhadji (2000) find positive effects of financial depth on economic growth. ${ }^{25}$ These results provide clear evidence that there is a long-run relationship between output and financial policy, and therefore the casual relationship runs from financial policy to output. ${ }^{26}$ Since the magnitude of financial policy (financial sector development index) is higher than that of real interest rate which support the argument that in a developing country like Pakistan the availability of funds rather the cost of funds is an important to raise real income. The low coefficient of real interest rate implies that an increase in interest rate alone is unable to expedite economic growth. These findings are consistent with earlier findings derived by Khan, et al. (2005).

Table 6

ARDL Estimates

\begin{tabular}{|c|c|c|}
\hline \multicolumn{3}{|c|}{ Dependent Variable: $L R G D P$} \\
\hline Regressor & Coefficient & $t$-values \\
\hline \multicolumn{3}{|c|}{ Panel A: Long-run Coefficients } \\
\hline LFSDI & 1.0291 & $3.4511 *$ \\
\hline$P D R$ & 0.0329 & $3.0555 *$ \\
\hline LTOPEN & 0.3715 & $8.3371 *$ \\
\hline Intercept & 9.9908 & $33.5708 *$ \\
\hline \multicolumn{3}{|c|}{ Panel B: Short-run Diagnostic Test Statistics } \\
\hline$\chi_{S C(1)}^{2}$ & \multicolumn{2}{|c|}{0.16400} \\
\hline$\chi_{F F(1)}^{2}$ & \multicolumn{2}{|c|}{2.9289} \\
\hline$\chi_{N O(2)}^{2}$ & \multicolumn{2}{|c|}{1.6418} \\
\hline$\chi^{2} \operatorname{Het}(1)$ & \multicolumn{2}{|c|}{1.6413} \\
\hline
\end{tabular}

Note: ARDL $(1,1,1,0)$ selected on the basis of SBC. The full tables of the short run estimates are available from the author. $\chi_{S C}^{2}, \chi_{F F}^{2}, \chi_{N O}^{2}$ and $\chi_{H e t}^{2}$ are Lagrange multiplier statistics for test of residual correlation, functional from mis-specification, non-normal errors and heteroskedasticity, respectively. These statistics are distributed as Chisquare values with degree of freedom in parentheses.

\footnotetext{
${ }^{25}$ These studies utilised panel data for the empirical purpose.

${ }^{26} \mathrm{We}$ have also implemented cointegration test by taking financial sector development index (FSDI) as dependent variable, but we does not find any evidence of cointegration. The results are available from the authors.
} 
We also find a positive and significant impact of trade liberalisation policy on real GDP. This result imply that trade liberalisation allows market forces to channel resources towards relatively productive sectors and hence leads to a rise in efficiency. It also increases markets for new products and generates economies of scale. These results confirmed the earlier findings of Din, et al. (2003).

To find the short-run causality between real output and financial liberalisation policy and output and trade liberalisation policy, we have the error-correction model. The results of the error-correction model are given in Table 7. The estimated lagged error-correction term $\left(E C M_{t-1}\right)$ is negative and highly significant. This result supports the cointegration among the variables

Table 7

Error Correction Representation of ARDL Model

\begin{tabular}{|c|c|c|}
\hline \multicolumn{3}{|c|}{ Dependent Variable: $\triangle L R G D P$} \\
\hline Regressor & Coefficient & $t$-values \\
\hline \multicolumn{3}{|c|}{ Panel A: Results of Error -Correction Model } \\
\hline$\triangle L F S D I$ & -0.0806 & -1.7654 \\
\hline$\triangle R D R$ & 0.0057 & $4.2958^{*}$ \\
\hline$\triangle L T O P E N$ & 0.0334 & $2.6122 * *$ \\
\hline$\Delta$ Intercept & 0.8974 & $3.3162 *$ \\
\hline$E C M_{t-1}$ & -0.0898 & $-3.0555^{*}$ \\
\hline $\mathrm{R}^{2}$ & \multicolumn{2}{|c|}{0.36} \\
\hline$R_{\text {adj }}^{2}$ & \multicolumn{2}{|c|}{0.25} \\
\hline F-stat & \multicolumn{2}{|c|}{5.066} \\
\hline AIC & \multicolumn{2}{|c|}{97.4013} \\
\hline SBC & \multicolumn{2}{|c|}{91.2371} \\
\hline S.E Regression & \multicolumn{2}{|c|}{0.02} \\
\hline R.S.S & \multicolumn{2}{|c|}{0.20} \\
\hline Equation-LL & \multicolumn{2}{|c|}{104.4013} \\
\hline DW-stat & \multicolumn{2}{|c|}{2.12} \\
\hline \multicolumn{3}{|c|}{$\begin{array}{c}\text { Panel B: Short-run Causality Tests between Output and Financial } \\
\text { Development and Output and Trade Liberalisation }\end{array}$} \\
\hline$\Delta L G S D I=0$ & \multicolumn{2}{|c|}{$\triangle L T O P E N=0$} \\
\hline$\chi^{2}(1)=3.1167$ & \multicolumn{2}{|c|}{$\chi^{2}(1)=6.8237^{*}$} \\
\hline
\end{tabular}


represented by Equation (2). The feedback coefficient is -0.09 , suggesting a slow adjustment process. Nearly 9 percent of the disequilibria of the previous period's shock adjust back to the long run equilibrium in the current year. The results further suggest that in the short-run financial sector development index exerted negative and insignificant impact on the economic growth. This result implies that economic growth is long run process not short-run.

The $\chi^{2}$-test for the hypothesis that the changes in financial sector development $(\triangle L F S D I)$ do not contribute to growth is not rejected, therefore there is not evidence of short-run causality between output and financial sector development. However, the hypothesis that there is short-run causality between output and trade liberalisation does not rejected as indicated by the $\chi^{2}$ test (panel $\mathrm{B}$ of Table 7). This result implies that there is interdependence between output and trade liberalisation. The short- run response of real deposit rate is significant but very small, suggesting that there is a need for further liberalisation of interest rate. Furthermore, the changes in the trade policy exerted positive and significant impact on economic growth in the short-run. However, the impact of trade policy changes is so small in the short run.

To assess the structural stability of the estimated model, we also performed the CUSUMSQ test of stability. Figures 4 and 5 plots the CUSUM and CUSUMSQ.
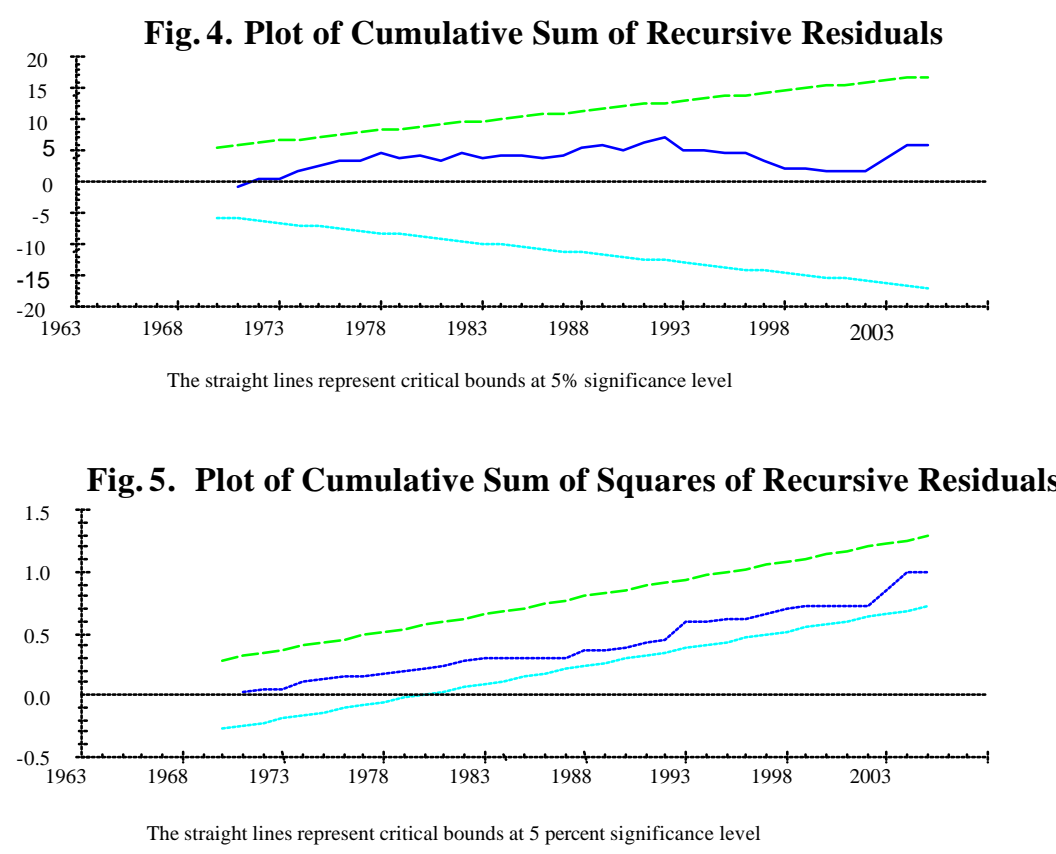
It can be seen respectively from the Figures 4 and 5 that the plots of CUSUM and CUSUMSQ statistic is well within the critical bounds implying that all the coefficients in the estimated model are stable.

The financial markets liberalisation affects the cost of external finance and facilitates trade liberalisation. Thus the policy makers should focused their attention on the creation of modern financial institutions, in the banking and stock markets.

\section{CONCLUSIONS}

This paper examines the impact of trade and financial policies and real interest rate on real GDP in Pakistan over the period 1961-2005. The study utilised bound testing approach of cointegration advanced by Pesaran, et al. (2001). Empirical results reveal the presence of a long-run relationship between real GDP, trade liberalisation, financial development and real interest rate. The results further show that in the long-run FSDI, RDR and LTOPEN exerted positive impact on real GDP. However, in the short run FSDI exerted negative association with economic growth, but remain statistically insignificant. The study also found a positive impact of trade openness on economic growth both in the long as well as in the short-run. This result highlighted the importance of trade liberalisation in order to enhance economic growth. However, financial liberalisation has relatively higher impact of real GDP than does trade liberalisation in the long-run. The low effectiveness of real interest rate indicates that interest rates alone are unlikely to expedite economic growth. The feed back coefficient is negative and significant, but the speed of adjustment is rather slow.

Based on these findings, the study suggests that Pakistan should go more of trade and financial liberalisation to enhance more economic growth. Further, the continuation of such policies with strong commitment is also recommended in order to promote and sustained economic growth.

\section{REFERENCES}

Ahmed, S. M., and M. I. Ansari (1998) Financial Sector Development and Economic Growth: The South-Asian Experience. Journal of Asian Economics 9:3, 503-517.

Andersen, T., and F. Tarp (2003) Financial Liberalisation, Financial Development and Economic Growth in LDCs. Journal of International Development 15, 189-209.

Ansari, M. I. (2002) The Impact of Financial Development, Money, and Public Spending on Malaysia National Income: An Econometric Study. Journal of Asian Economics 13, 72-93. 
Anwar, Tilat (2002) Impact of Globalisation and Liberalisation on Growth, Employment and Poverty: A Case Study of Pakistan. (WIDER Discussion Paper No. 17.)

Arestis, P., P. O. Demetriades, and K. B. Luintel (2001) Financial Development and Economic Growth: The Role of Stock Markets. Journal of Money, Credit and Banking 33, 16-41.

Aziz, Jahangir, and Christoph Duenwald (2002) Growth-Finance Intermediation Nexus in China. International Monetary Fund, Washington, D.C. (IMF Working Paper No. WP/02/194.)

Bagehot, W. (1783) Lombard Street. Homewood, IL: Irwin.

Bahmani-Oskooee, and R. C. W. Ng (2002) Long Run Demand for Money in Hong Kong: An Application of ARDL Model. International Journal of Business and Economics 1, 147-155.

Bahmani-Oskooee, M., and M. T. Bohl (2000) German Monetary Unification and the Stability of German M3 Money Demand Function. Economic Letters 66, 203-208.

Balassa, Bela (1978) Exports and Economic Growth: Further Evidence. Journal of Development Economics 5:2, 181-189.

Balassa, Bela (1985) Exports Policy Choices and Economic Growth in Developing Countries after 1973 Oil Shock. Journal of Development Economics, pp. 23-35.

Bandiera, O., G. Caprio, P. Honohan, and F. Schiantarelli (2000) Does Financial Reforms Raise or Reduce Savings? Review of Economic and Statistics 82:2

Barro, R. J. (1991) Economic Growth in a Cross Section of Countries. Quarterly Journal of Economics 106, 407-444.

Batra, R. (1992) The Fallacy of Free Trade. Review of International Economics $1,19-31$.

Batra, R., and D. J. Slottje (1993) Trade Policy and Poverty in the United States: Theory and Evidence, 1947-1990. Review of International Economics 1, 189-208.

Beck, T., R. Levine, and N. Loyaza (2000) Finance and the Sources of Growth. Journal of Financial Economics 58, 261-300.

Bell, C., and Peter L. Rousseau (2001) Post-independence India: A Case of FinanceLed Industrialisation? Journal of Development Economics 65, 153-175.

Bencivenga, V. R, and B. D. Smith (1991) Financial Intermediation and Endogenous Growth. Review of Economic Studies 58:2, 195-209.

Bencivenga, V.R, B. D. Smith, and R. Starr (1995) Transaction Costs, Technological Choice and Endogenous Growth. Journal of Economic Theory 67, 153-177.

Bernstein, D. J. (2000) To What Degree Do Central Banks Sterilise the Effects of Capital Flows on Domestic Money Supply? Applied Economic Letters 7, $1,15-19$. 
Berthelemy, J. C., and A. Varoudakis (1998) Financial Development, Financial Reforms and Growth: A Panel Data Approach. Revue-Economique 49:1, 195-206.

Bhagwati, J. (1988) Export-Promoting Trade Strategy: Issues and Evidence. The World Bank Research Observer 27-57.

Chang, T., and Yuan-Hong Ho (2002) Financial Development and Economic Growth in South Korea: A Note on Testing Demand-Following or Supply Leading Hypothesis. The Indian Economic Journal 77: 2, 153-160.

Clarke, R. (1996) Equilibrium Interest Rates and Financial Liberalisation in Developing Countries. Journal of Development Studies 32:3, 391-413.

Darrat, Ali F. (1999) Are Financial Deepening and Economic Growth Causality Related? Another Look at the Evidence. International Economic Journal $13: 3,19-35$.

Darrat, Ali F., Khalid Elkhal, and B. McCallum (2006) Finance and Macroeconomic Performance: Some Evidence for Emerging Markets. Emerging Markets Finance and Trade 42:3, 5-28.

De Gregorio, J., and P. E. Guidotti (1995) Financial Development and Economic Growth. World Development 23:3, 433-448.

De La Fuente, A., and J. M. Marin (1994) Innovations, Bank Monitoring and Endogenous Financial Development. Universitat Pompeu Fabra (Working Paper No. 59.)

Demetriades, P. O., and A. K. Hussein (1996) Does Financial Development Cause Economic Growth? Time Series Evidence from 16 Countries. Journal of Development Economics 51, 387-411.

Demetriades, P. O., and Kul B. Luintel (1996) Financial Development, Economic Growth and Banking Sector Controls: Evidence From India. Economic Journal 106, 359-374.

Din, Musleh-UD, E. Ghani, and O. Siddique (2003) Openness and Economic Growth in Pakistan. The Pakistan Development Review 42:4, 795-807.

Dollar, David (1992) Outward-Oriented Developing Economies Really Do Grow More Rapidly: Evidence from 95 LDCs, 1976-85. Economic Development and Cultural Change 40: 3, 553-544.

Edwards, S. (1992) Trade Orientation, Distortions, and Growth in Developing Countries. Journal of Development Economics 39, 31-57.

Edwards, S. (1998) Openness, Productivity and Growth: What Do we Really Know? Economic Journal 108: 447, 383-398.

Engle, R. F., and C.W.J. Granger (1987) Cointegration and Error Correction: Representation, Estimation and Testing. Econometrica 55: 2, 251-276.

Fase, M., and R. Abma (2003) Financial Environment and Economic Growth in Selected Asian Countries. Journal of Asian Economics 12, 11-21.

Feder, G. (1983) On Exports and Economic Growth: An Empirical Investigation. Journal of Development Economics 59-73. 
Fry, M. J. (1997) In Favour of Financial Liberalisation. Economic Journal 107, $754-770$

Ghatak, S. (1997) Financial Liberalisation: The Case of Sri Lanka. Empirical Economics 22:1, 117-131.

Goldsmith, R. W. (1969) Financial Structure and Development. New Haven, C.T. Yale University Press.

Greenway, D., M. Wyn, and P. Wright (2002) Trade Liberalisation and Economic Growth in Developing Countries. Journal of Development Economics 67:1, 229-244.

Greenwood, J., and B. Jovanovic (1990) Financial Development, Growth and the Distribution of Income. Journal of Political Economy 98:5, 1076-1107.

Greenwood, J., and B. Smith (1997) Financial Markets in Development and the Development of Financial Markets. Journal of Economic Dynamic and Control 21, 145-181.

Gupta, K. L. (1984) Finance and Economic Growth in Developing Countries. London: Croom Helm.

Gurley, J. G., and E. S. Shaw (1955) Financial Aspects of Economic Development. American Economic Review 45: 4, 515-538.

Haque, Nadeem Ul, and Shahid Kardar (1993) Constraints to the Development of Financial Markets in Pakistan. (IMF Mimeographed.)

Hicks, J. ((1969) A Theory of Economic History. Oxford: Clarendon Press.

Husain, Ishrat (2005) Economy of Pakistan: An Overview. Key Note Address at the Expo 2005 Conference held at Karachi on February 3.

Iimi, Atsushi (2004) Banking Sector Reforms in Pakistan: Economies of Scale and Scope, and Cost Complementarities. Journal of Asian Economics 15, 507-528.

Iqbal Zafar, and G. M. Zahid (1998) Macroeconomic Determinants of Economic Growth in Pakistan. The Pakistan Development Review 37: 2, 125-48.

Ireland, P. N. (1994) Money and Growth: An Alternative Approach. American Economic Review 47-65.

Irwin, A. Douglas, and M. Tervio (2002) Does Trade Raise Income? Evidence from the Twentieth Century. Journal of Development Economics 58:1, 1-18.

Jayaratne, J., and P. Strahan (1996) The Finance-Growth Nexus: Evidence from Bank Branch Deregulation. Quarterly Journal of Economics 111:3, 639-670.

Jin, Jang C. (2000) Openness and Growth: An Interpretation of Empirical Evidence from East Asian Countries. The Journal of International Trade and Economic Development 9:1, 5-17.

Johansen, S. (1988) Statistical Analysis of Cointegrating Vectors. Journal of Economic Dynamics and Control 12, 231-254.

Johansen, S. (1991) Estimation and Hypothesis Testing of Cointegrating Vectors in Gaussian Vector Autoregressive Models. Econometrica 59, $1551-1580$. 
Johansen, S., and K. Juselius (1990) Maximum Likelihood Estimation and Inference on Cointegration-With Application to the Demand for Money. Oxford Bulletin of Economics and Statistics 52, 169-210.

Jung, W. S. (1986) Financial Development and Economic Growth: International Evidence. Economic Development and Cultural Change 34: 2, 333-346.

Kelly, R., and G. Mavrotas (2003) Financial Sector Development-Futile or Fruitful? An Examination of the Determinants of Savings in Sri Lanka. United Nations University. (WIDER Discussion Paper No. 14.)

Kemal, A. R. (2001) Globalisation and South Asia. Mahbub Ul Haq Human Development Review 1:1, 61-74.

Kemal, A. R., Musleh-ud Din, U. Qardir, L. Fernando, and S. Colombage (2002) Exports and Economic Growth in South Asia. A Study Prepared for the South Asia Network of Economic Research Institutes.

Khan, A. H., Afia Malik, and Lubna Hasan (1995) Exports, Growth and Causality: An Application of Cointegration and Error-Correction Modelling. The Pakistan Development Review 34:4, 1001-1012.

Khan, A. H., and Lubna Hasan (1998) Financial Liberalisation, Savings, and Economic Development in Pakistan. Economic Development and Cultural Change 46, 3, 581-597.

Khan, M. Arshad (2003) Restructuring of Financial Sector in Pakistan. Journal of the Institute of Bankers Pakistan 70, 49-68.

Khan, M. Arshad, Abdul Qayyum, and Saeed Ahmed Sheikh (2005) Financial Development and Economic Growth: The Case of Pakistan. The Pakistan Development Review 44:4.

Khan, S. M., and A.S. Senhadji (2000) Financial Development and Economic Growth: An Overview. Washington, D.C: International Monetary Fund. (IMF Working Paper 00/209.)

King, R. G., and R. Levine (1993a) Finance and Growth: Schumpeter Might be Right. Quarterly Journal of Economics 108, 717-737.

King, R. G., and R. Levine (1993b) Finance, Entrepreneurship and Growth. Journal of Monetary Economics 32,30-71.

Krueger, Anne O. (1998) Why Trade Liberalisation is Good for Growth. Economic Journal 1513-1522.

Kwan, A. C., Y. Wu, and J. Zhang, (1998) An Exogeneity Analysis of Financial Deepening and Economic Growth: Evidence from Hong Kong, South Korea, and Taiwan. Journal of International Trade and Economic Development 7:3, 339-354.

Leamer, E. E. (1995) A Trade Economist's View of U.S. Wages and Globalisation. Brooking Conference Proceedings.

Lee, Jong-Wha (1993) International Trade Distortions, and Long-run Economic Growth. IMF Staff Papers 299-328. 
Levine, R. (1997) Financial Development and Economic Growth: Views and Agenda. Journal of Economic Literature 35, 688-726.

Levine, R. (1998) The Legal Environment, Banks, and the Long-Run Economic Growth. Journal of Money, Credit and Banking 30: 3, 596-613.

Levine, R. (1999) Financial Development and Growth: Where Do We Stand. Estudios de Economia 26: 2, 113-136.

Levine, R. (2002) Bank-Based or Market-Based Financial Systems: Which is Better? Journal of Financial Intermediation 11, 398-428.

Levine, R. (2004) Finance and Growth: Theory and Evidence. (NBER Working Paper No. 10766.)

Levine, R., and D. Renelt (1992) A Sensitivity Analysis of Cross-Country Growth Regressions. American Economic Review 82, 942-963.

Levine, R., and S. Zervos (1998) Stock Markets, Banks and Economic Growth. American Economic Review 88: 3, 537-558.

Levine, R., Norman Loayza, and Thorsten Beck (2000) Financial Intermediation and Growth: Causality and Causes. Journal of Monetary Economics 46, 3177.

Lucas, R.E. Jr. (1988) On the Mechanics of Economic Development. Journal of Monetary Economics 22, 3-42.

Mckinnon, R. I. (1973) Money and Capital in Economic Development. Brooking Institution, Washington, D.C

Michaelpoulos, C., and K. Jay (1973) Growth of Exports and Income in Developing World: A Neoclassical View. (AID Paper No. 28.)

Michaely, Michael (1973) Exports and Economic Growth: An Empirical Investigation. Journal of Development Economics 18, 49-54.

Mohsin, M. H, M. A. Kemal, and U. Qadir (2001) Impact of Trade Reforms on Poverty. Pakistan Institute of Development Economics, 16th Annual General Meeting: Islamabad.

Odedokun, M. O. (1998) Financial Intermediation and Economic Growth in Developing Countries. Journal of Economic Studies 25, 203-224.

Patrick, H. T. (1966) Financial Development and Economic Growth in Underdeveloped Countries. Economic Development and Cultural Change 14: 2, 174-187.

Pesaran, M. H., and Y. Shin (1995) Long-run Structural Modelling. Department of Applied Economics, University of Cambridge, Cambridge, MA (DAE Working Paper No. 9419.)

Rajan, R. G., and L. Zingalas (1996) Financial Dependence and Growth. University of Chicago. (Mimographed.)

Rajan, R. G., and L. Zingalas (1998) Financial Dependence and Growth. American Economic Review 88:3, 559-586.

Ram, Rati (1985) Exports and Economic Growth: Some Additional Evidence. Economic Development and Cultural Change 33: 415-425. 
Ram, Rati (1999) Financial Development and Economic Growth: Additional Evidence. Journal of Development Studies 35: 4, 164-174.

Rivera-Batiz, L. A., and P. M. Romer (1991) International Trade with Endogenous Technological Change. European Economic Review 971-1004.

Robinson, J. (1952) The Rate of Interests and Other Essays. Macmillan, London.

Rodriguez, F., and D. Rodrik (1999) Trade Policy and Economic Growth: A Skeptic's Guide to the Cross-National Evidence. (NBER Working Paper No. 7081.)

Romer, P.M. (1986) Increasing Returns and Long-run Growth. Journal of Political Economy 1002-1037.

Roubini, Nouriel, and Xavier Sala-i-Martin (1991) Financial Development, Trade Regimes and Economic Growth. (NBER Working Paper No. 3876.)

Rousseau, P. L., and Dadanee Vuthipadadorn (2005) Finance, Investment, and Growth: Time Series Evidence from 10 Asian Economies. Journal of Macroeconomics 27, 87-106.

Rousseau, P. L., and P. Wachtel (1998) Financial Intermediation and Economic Performance: Historical Evidence from Five Industrialised Countries. Journal of Money, Credit and Banking 30:4, 657-678.

Sachs, J. D., and A Warner (1995) Economic Reforms and the Process of Global Integration. Brooking Papers on Economic Activity 1, 1-118.

Schumpeter, J. A. (1911) Theorie der Wirtschaftlichen Entwicklung [The Theory of Economic Development]. Leipzig: Dunker and Humblot, translated by Redvers Opie. Cambridge, MA: Harvard University Press, 1934.

Shaw, E. S. (1973) Financial Deepening in Economic Development. Cambridge, M.A.: Havard University Press.

Singh, A., and B. A. Weisse (1998) Emerging Stock Markets, Portfolio Capital Flows and Long-Term Economic Growth: Micro and Macroeconomic Perspectives. World Development 26: 4, 607-622.

Sinha, Dipendra, and Joseph Macri (2001) Financial Development and Economic Growth: The Case of Eight Asian Countries. Economia Internazionale 54:2, 218-234.

Spears, A. (1992) The Role of Financial Intermediation in Economic Growth in SubSaharan Africa. Canadian Journal of Development Studies 13: 3, 361-380.

Stock, J. H., and M. W. Watson (1988) Variable Trend in Economic Time Series. Journal of Economic Prospective 1, 147-174.

Sukar, Abdulhamid, and G. Ramakrishna (2002) The Effect of Trade Liberalisation on Economic Growth: The case of Ethiopia. Finance India $16: 4,1295-1305$.

Tadesse, S. (2002) Financial Architecture and Economic Performance: International Evidence. Journal of Financial htermediation 11, 429454. 
Tang, Cheong Tuck (2001) Bank Lending and Inflation in Malaysia: Assessment from Unrestricted Error-Correction Models. Asian Economic Journal 15:3, 275-289.

Tang, Cheong Tuck (2002a) Demand for M3 and Expenditure Components in Malaysia: An Assessment from Bound Testing Approach. Applied Economic Letters 9, 721-725.

Theil, H. (1971) Principles of Econometrics. London: North Holland.

Thornton, J. (1996) Financial Deepening and Economic Growth in Developing Economies. Applied Economic Letters 3: 4, 243-246.

Tyler, William G. (1981) Growth and Export Expansion in Developing Countries. Journal of Economic Development 9, 121-130.

World Bank (1989) World Development Report 1989. New York: Oxford University Press.

Yang, Y., and Y. Haung (1997) Impact of Trade Liberalisation on Income Distribution in China. (Economic Division Working Paper No. 1.)

Yanikkaya, Halit (2003) Trade Openness and Economic Growth: A CrossCountry Empirical Investigation. Journal of Development Economics 72:1, 57-89.

Yasmin, Bushra, Zainab Jehan, and M. A. Chaudhary (2006) Trade Liberalisation and Economic Development: Evidence from Pakistan. The Lahore Journal of Economics 11: 1, 19-34. 